\title{
Physiological controls on the distribution of the macroalga Spyridea hypnoides: patterns along a eutrophication gradient in Bermuda
}

\author{
Karen J. McGlathery* \\ Section of Ecology and Systematics, Division of Biological Sciences, Corson Hall, Cornell University, Ithaca, \\ New York 14853, USA
}

\begin{abstract}
Physiological controls on the pattern of macroalgal distribution were determined along a nutrient gradient in a subtropical bay in Bermuda, where filamentous mat-forming macroalgae, primarily Spyridea hypnoides, dominated the eutrophic inner bay but were absent from the lownutrient outer bay. My related work showed that these macroalgae responded favorably to nutrient additions in the inner bay, increasing significantly in abundance after $10 \mathrm{wk}$. In this study, I tested the hypothesis that $S$. hypnoides was absent from the low-nutrient outer bay because its metabolic nitrogen demands exceeded its nitrogen storage capacity and its ability to acquire nitrogen at low ambient concentrations to replenish depleted internal pools. I transplanted S. hypnoides from the high-nutrient inner bay to the low-nutrient outer bay, and compared these transplants to macroalgae handled and transplanted in situ and to unmanipulated controls. Tissue nitrate concentrations declined by $93 \%$ in the outer-bay transplants after $4 \mathrm{~d}$ and remained at near undetectable levels for the duration of the study (14 d). Protein and chlorophyll contents also declined significantly in these transplants, by 55 and $75 \%$ respectively. Nitrogen-deficient macroalgae showed an increase in photosynthetic efficiency per unit chlorophyl; however, dark respiration was $2 \times$ higher than that of nutrient-sufficient macroalgae. Biomass-specific carbon gain was significantly reduced for the nutrient-stressed outer-bay transplants, where maximum rates of photosynthesis were $75 \%$ lower than those for macroalgae from the highnutrient inner bay. This study suggests that the physiological cost of high metabolic nitrogen demands is a low nutrient storage capacity and a greater vulnerability to nutrient stress when ambient nutrient concentrations are chronically low.
\end{abstract}

\section{INTRODUCTION}

Species distributions in marine macrophyte communities reflect, in part, physiological constraints on resource acquisition and use. Macroalgae that are characteristic of high nutrient habitats are typically filamentous or sheet-like in form and tend to have rapid nutrient uptake and growth potentials (Fujita 1985). This is due in large part to the high surface area : volume ratio and structural simplicity of these species, both of which maximize nutrient uptake and photosynthetic

\footnotetext{
- Present addresses: Freshwater Biological Laboratory, University of Copenhagen, Helsingørsgade 51, DK-3400 Hillerød, Denmark, and the National Environmental Research Institute, 25 Vejlsøvej, PO Box 314, DK-8600 Silkeborg, Denmark
}

efficiency (Rosenberg \& Ramus 1984, Carpenter 1990). The high metabolic demands for growth and maintenance, however, must be met by rapid uptake in response to nutrient pulses, as these macroalgae typically have low nutrient storage reserves (Rosenberg \& Ramus 1982, Fujita 1985, Duke et al. 1989). Internal nutrient stores allow macroalgae to average nutrient supply over time by supporting maintenance and growth requirements between nutrient pulses. Species which do not have a well-developed storage capacity, therefore, experience a variable nutrient supply and may be more vulnerable to stress when the nutrient levels are chronically low or the when the resupply via nutrient pulses is rare. Nitrogen-stressed macroalgae may show a decline in both organic (e.g. pigments, amino acids, proteins) and inorganic nitrogen stores (Ryther et al. 1981, Bird et al. 1982, Asare \& Harlin 1983, Lapointe \& Duke 1984, 
Thomas \& Harrison 1985, Hwang et al. 1987), as well as reduced growth and photosynthetic rates (Lapointe \& Duke 1984).

Although the relationship between macroalgal functional morphology and the capacities for nutrient uptake and storage have been well studied in the laboratory (Rosenberg \& Ramus 1982, Fujita 1985, Ramus \& Venable 1987, Duke et al. 1989), there have been few direct applications of this concept to patterns of macroalgal distribution in the field. In this study, I was interested in determining if the capacity for nutrient acquisition and use by the macroalga Spyridea hypnoides (Rhodophyceae, Ceramiales) influenced its distribution in a subtropical lagoon on Bermuda's north shore. Bailey's Bay is a shallow (1 to $3 \mathrm{~m}$ ) semiprotected lagoon with a nutrient gradient of some $200 \mathrm{~m}$ extending from the shore seaward. Eutrophication of the inner bay, presumably resulting from groundwater inputs, resulted in nitrate concentrations that were 2 to $10 \times$ higher than that of the outer bay. However, both ammonium and soluble reactive phosphorus (SRP) concentrations were consistently low throughout the bay; ammonium ranged from $<0.05$ to $0.5 \mu \mathrm{M}$ and phosphorus was $<0.05 \mu \mathrm{M}$. Within the bay, the distribution of $S$. hypnoides was strongly correlated with ambient nitrate levels in the water column. $S$. hypnoides dominated the seagrass-macroalgal community in the inner, eutrophic part of the bay, but was absent beyond $40 \mathrm{~m}$ from shore where nutrient concentrations were chronically low. In a previous nutrient enrichment experiment, I showed that elevated nutrient levels in the water column caused a significant increase in the abundance of $S$. hypnoides and other filamentous, mat-forming macroalgae in the inner bay (McGlathery 1992). In this study, I tested the hypothesis that $S$. hypnoides was absent from the outer, low-nutrient part of the bay because its metabolic nitrogen demands exceeded its nitrogen storage capacity and its ability to acquire nutrients at low ambient concentrations. I did this by comparing the physiological performance of macroalgae in the highnutrient inner bay, where they were dominant, with those transplanted to the low-nutrient outer bay. This study addressed the assumption that there is a tradeoff between the allocation of acquired nutrients to growth and storage and that a physiological cost of a rapid growth potential is a lower nutrient storage capacity and a greater vulnerability to nutrient stress.

\section{MATERIALS AND METHODS}

Transplant experiment. To evaluate the physiological response of Spyridea hypnoides to differences in nutrient conditions, I transplanted macroalgae from the inner (high nutrient) to the outer (low nutrient) part of the bay, and compared these with macroalgae handled and transplanted in place for 2 wk during July 1991. Approximately $50 \mathrm{~g}$ (wet $w \mathrm{t}$ ) of the filamentous macroalgae were transplanted into each of 3 replicate cages in both the inner and outer parts of the bay. The roofless cages were constructed of $45 \mathrm{~cm}$ high plasticcoated garden fencing (2.5 cm mesh), enclosing an area of $0.8 \mathrm{~m}^{2}$. The cages served principally to keep the macroalgae in place with minimal effects on boundary layer conditions. Little fouling of the mesh occurred over the $2 \mathrm{wk}$ study period. No attempt was made to prevent grazing by the dominant herbivorous fish Sparisoma sp., as a previous experiment showed that herbivory was not a major determinant of $S$. hypnoides distribution in this bay (McGlathery 1992). I measured ambient light levels in both the inner and outer parts of the bay using a Li-Cor LI-1000 light meter and placed the 3 replicate cages at $0.5 \mathrm{~m}$ depth in the inner bay and 3 at $1.0 \mathrm{~m}$ depth in the outer bay (at low tide) so that the macroalgae at both sites were exposed to equal light intensities throughout the study period. Light intensities in the cages differed by $<5 \%$ between sites over the 2 wk experiment. To determine if there was an effect of the transplanting procedure on the macroalgae, I compared the physiological characteristics of macroalgae transplanted in situ in the inner bay with macroalgae collected within the vicinity of the cages (unmanipulated controls).

Over the course of the experiment I measured water column nitrite+nitrate levels every $2 \mathrm{~d}$ at both locations within the bay. Triplicate water samples were collected at each site usually within $1 \mathrm{~h}$ of low tide, immediately filtered through Whatman GF/F $(0.7 \mu \mathrm{m})$ glass fiber filters and frozen for later analysis. Frozen samples were analyzed within 1 mo as nitrite, following cadmium reduction on a Scientific Instruments AP-100 autoanalyzer (Grasshoff et al. 1983). Three analytical replicates were run for each water sample.

Tissue analyses. I collected samples of the filamentous macroalgae ca every $2 \mathrm{~d}$ for the analyses of dissolved internal nitrite+nitrate pools and total tissue carbon, nitrogen, and phosphorus concentrations. Triplicate samples were harvested from each of the 3 cages at both locations and from the area adjacent to the cages in the inner bay (representing the unmanipulated controls). After rinsing the samples briefly in deionized water, I determined tissue nitrite+nitrate (hereafter referred to as tissue nitrate) pools using an ethanol extraction, following the method of Hwang et al. (1987). Macroalgal samples were blotted dry and $1.0 \mathrm{~g}$ (wet $\mathrm{wt}$ ) of tissue was ground in $10 \mathrm{ml}$ of $90 \%$ $(v / v)$ ethanol with a mortar and pestle. The samples were extracted overnight in the dark at room temperature and a $3 \mathrm{ml}$ subsample of the ethanol extract was 
then taken and diluted to $30 \mathrm{ml}$ with deionized water and frozen for later analysis. Tissue nitrate pools were determined spectrophotometrically as nitrite as described previously. I corrected the concentrations of dissolved nitrite+nitrate for absorbance by pigment color and initial extraction volume and expressed them as per $g$ (wet wt).

For the determination of total carbon, nitrogen and phosphorus content in the tissue, I dried macroalgal samples to a constant weight at $60^{\circ} \mathrm{C}$ and then ground them to a powder with a mortar and pestle, using liquid nitrogen to ensure maximum homogenization. Samples were collected from each cage and from the vicinity of the cages in the inner bay (unmanipulated controls) and $3 \mathrm{mg}$ subsamples were analyzed in duplicate for total carbon and nitrogen on a Carlo-Erba NA1500 CNS analyzer against a 'cloro' $\left(\mathrm{C}_{9} \mathrm{H}_{14} \mathrm{Cl} \mathrm{N}_{2} \mathrm{O}_{6} \mathrm{PS}\right)$ standard. Tissue phosphorus was determined by dry ashing replicate $5 \mathrm{mg}$ samples at $500^{\circ} \mathrm{C}$ for $4 \mathrm{~h}$ acid dissolution ( $2 \mathrm{ml} 1 \mathrm{~N} \mathrm{HCl}$ plus $10 \mathrm{ml}$ deionized water) at $104{ }^{\circ} \mathrm{C}$ for $2 \mathrm{~h}$, and subsequent colorimetric analysis (modified from Stainton et al. 1974). The total carbon, nitrogen and phosphorus contents are reported as a percent of the sample dry wt.

I determined the starch content of Spyridea hypnoides for samples harvested on the first and last days of the experiment, using a modification of the methods of Batey (1982) and Aman \& Hesselman (1984), which are based on the conversion of starch to glucose by the enzyme glucoamylase. Immediately upon collection, samples were rinsed with deionized water and freezedried for $24 \mathrm{~h}$, then ground to a fine powder with a mortar and pestle. Samples from the replicate cages in each site were pooled to achieve sufficient biomass for the assay. Triplicate tissue samples (75 to $100 \mathrm{mg}$ ) were weighed to the nearest $0.1 \mathrm{mg}$ and diluted with deionized water. The samples were digested for starch by incubating first with $25 \mathrm{ml}$ of heat-stable alphaamylase in a boiling water bath for $30 \mathrm{~min}$ and subsequently with $1.25 \mathrm{ml}$ of $2 \mathrm{M}$ sodium acetate buffer $(\mathrm{pH} \mathrm{4.8)}$ and $2.5 \mathrm{ml}$ of amyloglucosidase for $2 \mathrm{~h}$ at 55 to $60^{\circ} \mathrm{C}$. A $0.2 \mathrm{ml}$ aliquot of the cooled, centrifuged supernatent was subsampled for the colorimetric analysis of glucose. Sample blanks were run without the addition of the amylase enzyme to correct for free glucose in the macroalgal tissue $e_{i}$ all cases, the free glucose concentration of the freeze-dried samples was small, accounting for $<0.3 \%$ of the sample dry wt.

At the end of the experiment (Day 14) I determined the protein content of Spyridea hypnoides on pooled samples from each treatment. Macroalgal tissue was collected from the field, rinsed briefly with deionized water and immediately frozen for later analysis. The thawed tissue was then blotted dry and triplicate $100 \mathrm{mg}$ (wet wt) macroalgal samples were used in the
BCA (bicinchoninic acid) protein assay (Pierce Chemical Company, Rockford, IL, USA). This method has been shown to be more tolerant of interfering substances than the Lowry method (Smith et al. 1985) and tissues can be extracted in the presence of detergents, allowing the complete solubilization of membranebound hydrophobic proteins. The samples were ground in a tissue homogenizer and extracted overnight in a refrigerator in $5 \mathrm{ml}$ of $1 \%(\mathrm{w} / \mathrm{v})$ sodium dodecyl sulfate to solubilize the proteins. After warming to room temperature, the samples were centrifuged for $5 \mathrm{~min}(2600 \times \mathrm{g})$ and a $0.1 \mathrm{ml}$ aliquot of the supernatant was used for the protein assay. A combined reagent was added causing the liberated proteins to reduce $\mathrm{Cu}^{2+}$ to $\mathrm{Cu}^{+}$under alkaline conditions and the sodium salt of the BCA to complex with the cuprous ions produced during the $2 \mathrm{~h}$ incubation period. The protein concentration was determined colorimetrically against a bovine serum albumin standard, and normalized to the initial biomass ( $g$ wet $w t$ ).

Photosynthesis and respiration measurements. I compared the rates of photosynthesis and respiration between the transplanted algae and the unmanipulated controls on the final day of the experiment. The assay was conducted in a temperature-controlled (23 to $25^{\circ} \mathrm{C}$ ) algal culture room, with light provided by a bank of fluorescent $(400 \mathrm{~W})$ lamps. Macroalgae were collected from the field on the morning of the assay and maintained in separate $10 \mathrm{l}$ glass tanks containing water collected from the sample location until the measurements were made. Compressed air provided circulation in these holding tanks. I measured photosynthesis and respiration rates as changes in dissolved oxygen concentration in sealed glass chambers fitted with a BOD (biological oxygen demand) probe, with circulation provided by magnetic stirrers. About $1.0 \mathrm{~g}$ (wet wt) of Spyridea hypnoides was placed in each incubation chamber with $120 \mathrm{ml}$ of filtered $(0.22 \mu \mathrm{m})$ Sargasso seawater.

The oxygen concentration inside the incubation chambers was determined at 5 min intervals with an ENDECO Type 1125 pulsed dissolved oxygen system. This system measures oxygen concentration during the first $10 \mathrm{~s}$ of each sampling interval, and thus introduces little error from oxygen consumption by the probe. Measurements of oxygen concentration were made continuously until the rate of oxygen evolution stabilized, which typically required 15 to $20 \mathrm{~min}$. Four independent probes were monitored by the system, allowing simultaneous measurements of the 3 treatments and a seawater blank. I constructed photosynthesis vs irradiance ( $P$ vs I) curves from rates of oxygen evolution determined at different light intensities, which were achieved by using multiple layers of neutral density screening. I measured respiration rates 
as oxygen consumption by the macroalgae in complete darkness. At the end of the assay, samples were blotted dry and weighed to the nearest $0.1 \mathrm{~g}$, then ground with a mortar and pestle with $80 \%$ (v/v) acetone for chlorophyll a extraction. I determined the chlorophyll concentration spectrophotometrically after an overnight extraction using an extinction coefficient of $78.07 \mathrm{mM}^{-1} \mathrm{~cm}^{-1}$ (Kursar \& Alberte 1983). Photosynthesis and respiration rates are expressed either as $\mu \mathrm{mol} \mathrm{O} \mathrm{mg}^{-1} \mathrm{chl} \mathrm{a} \mathrm{min}^{-1}$ or $\mu \mathrm{mol} \mathrm{O} \mathrm{g}^{-1}$ wet wt $\mathrm{min}^{-1}$.

To compare the photosynthetic characteristics of Spyridea hypnoides between the treatments, I plotted gross photosythesis against irradiance for each individual sample and analyzed the curves by nonlinear regression. The 3 replicate response curves for each treatment were fit using the iterative least-squares procedure with the model:

$$
y=P_{\max }\left(1-e^{-\alpha x}\right)
$$

where $x=$ light intensity; $y=$ rate of oxygen evolution; $P_{\text {max }}=$ asymptotic level, representing light saturation of photosynthesis; and $\alpha=$ slope of the initial portion of the curve. I used the parameter estimates derived from the model to calculate the saturating irradiance $\left(I_{k}\right)$ as gross $P_{\max } / \alpha$, representing the irradiance level at which the extrapolated initial slope crosses the saturated rate of maximum photosynthesis, and the irradiance $\left(I_{c}\right)$, where net $P_{\max }$ equals zero.

Statistical analyses. I evaluated differences in the nutrient concentrations in the bay, and in the macroalgal tissue, using analysis of variance tests on the GLM (general linear modeling) procedure of SAS. For the time course data on tissue constituents, I used the analysis of variance with repeated measures test (ANOVAR). The assumption of compound symmetry of the variance-covariance matrix (homogeneity of variances) was evaluated from the Mauchly's criterion test statistic, and only in the case of tissue nitrate was the assumption violated. I still used the analysis based on corrected significance levels, as the Huynh-Feldt test indicated that there was very mild violation of the compound symmetry assumption (Potvin et al. 1990). Because the final (Day 14) macroalgal samples were pooled to achieve enough biomass for the different assays, I analyzed these data separately from the time course measurements using ANOVA tests of the GLM procudure. To evaluate treatment effects on the model generated estimates of $P_{\max }$ and $\alpha_{1}$ and on the calculated values of $I_{\mathrm{k}}$ and $I_{\mathrm{c}}$ I fitted each photosynthesis versus irradiance curve separately using the non-linear iterative procedure of SAS (NLIN). Treatment means for these parameters were compared using paired t-tests.

\section{RESULTS}

\section{Ambient nutrient conditions and tissue analyses}

Over the course of the experiment the nitrite + nitrate concentration in the water column was 2 to $10 \times$ higher in the inner bay, where Spyridea hypnoides was dominant, than in the outer bay (Fig. 1; $p<0.0001$, ANOVA). Nitrite + nitrate levels in the inner bay fluctuated during the 2 wk period with much of the variation being a function of the timing of water sampling. Samples with the lowest nitrite + nitrate concentrations (Days 0, 4, and 14) were taken close to high tide. In contrast, nitrite + nitrate levels in the outer bay were consistently low, with concentrations of about $1.0 \mu \mathrm{m}$ throughout the study period. Dissolved nitrate pools in macroalgal tissues were highly dependent on ambient nutrient conditions and the response of Spyridea hypnoides to transplanting between the inner and outer bays varied accordingly (Fig. 2; $p<0.001$, ANOVAR). For macroalgae from the high-nutrient inner bay, tissue nitrate pools roughly mirrored that of the water column (Fig. 2) and increased steadily over time. At the end of the $2 \mathrm{wk}$ experiment, tissue nitrate concentrations of macroalgae from the inner bay had increased 3-fold over starting levels. After $4 \mathrm{~d}$ in the low-nutrient outer bay, however, the tissue nitrate pools of transplants declined by $93 \%$ to undetectable levels and remained there throughout the study period (Fig. 2). These macroalgae had lost most pigment coloration by this time and were highly bleached relative to the macroalgae from the inner bay. By the end of the treatment period, tissue nitrate concentrations of macroalgae transplanted to the low-nutrient outer bay

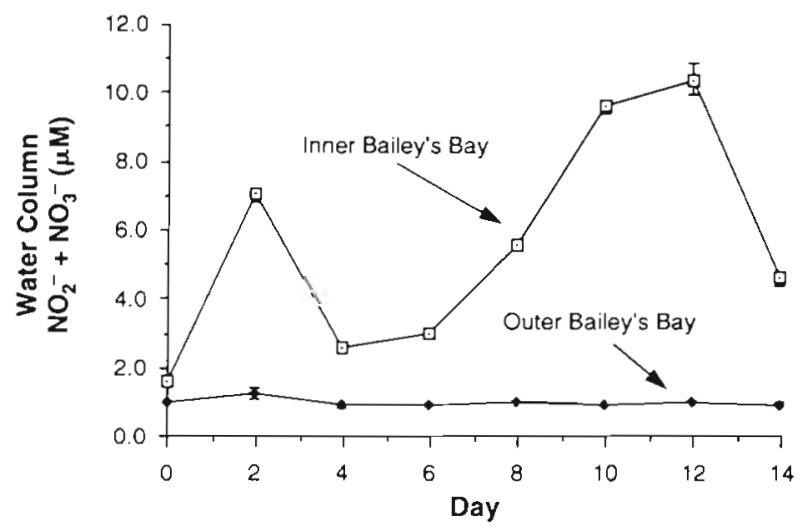

Fig. 1. Dissolved nitrite + nitrate concentrations in the water column of the high-nutrient inner and low-nutrient outer parts of Bailey's Bay during the 2 wk transplant experiment With the exception of Days 0,4 , and 14 , samples were collected within 1 h of low tide. Values represent means ( $\pm 1 \mathrm{SE}$ ) of 3 samples collected at each site; 3 analytical replicates were run on each sample 


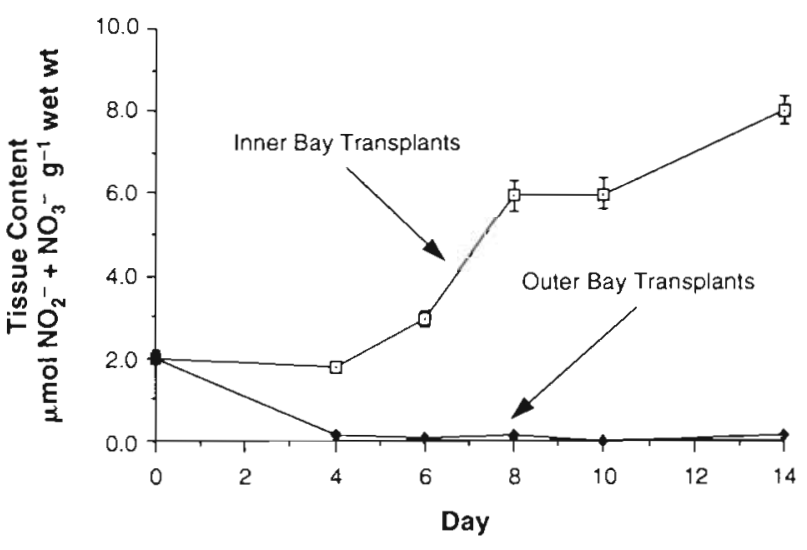

Fig. 2. Spyridea hypnoides. Internal dissolved nitrite + nitrate pools in the tissue transplants in the inner (high nutrient) and outer (low nutrient) parts of Bailey's Bay. The average pool size was determined for each replicate cage from triplicate samples collected on Days 4 to $10_{i}$ reported values are treatment means ( $\pm 1 \mathrm{SE}$ ) determined from these averages. At the start and finish of the experiment (Days 0 and 14), samples were pooled to determine treatment means $(n=3) \pm 1 \mathrm{SE}$

were only $2 \%$ of that of macroalgae remaining in situ (Table 1; $p<0.0001$, ANOVA).

Both protein and chlorophyll a concentrations also declined significantly in macroalgae exposed to the low nutrient conditions of the outer bay as compared to macroalgae in the inner bay (Table 1; $p<0.001$ and $p<0.01$ respectively, ANOVA). At the end of the $2 \mathrm{wk}$ experiment, the protein content of the transplanted Spyridea hypnoides was $55 \%$ lower than that of macroalgae remaining in the high-nutrient inner bay. Chlorophyll a concentrations (per g wet wt) of macroalgae in the outer bay declined to $25 \%$ of that of macroalgae in the inner bay after 2 wk. For all the nitrogen-based tissue constituents (nitrate, protein, chlorophyll), there were no significant differences between the macroalgae transplanted to cages in the inner bay and the unmanipulated control algae harvested in the vicinity of the cages (Table $1 ; p>0.05$, ANOVA). After $14 \mathrm{~d}$, there was a significant difference in the starch content of the macroalgal transplants between the inner and outer bay (Table 1; $p<0.01$,
ANOVA). The starch concentration (wt \%) of transplants to the outer bay was approximately $35 \%$ lower than that of inner bay transplants at the end of the treatment period. However, there were no significant differences between these outer bay transplants and the unmanipulated control algae in the inner bay (Table $1 ; p>0.05$, ANOVA). These values were also quite similar to the starch content of $S$. hypnoides at the start of the experiment $(3.54 \pm 0.10 \mathrm{wt} \%)$. Thus it appears that the difference between the transplants is largely a function of an increased starch content of the macroalgae in the inner bay over the course of the experiment rather than of a marked decline in the starch content of the outer bay transplants.

At both sites, the \% carbon content of the macroalgae increased initially and then declined continuously after $4 \mathrm{~d}$ (Fig. 3; p > 0.05, ANOVAR). By the end of the 2 wk experiment, however, the macroalgae transplanted to the low-nutrient outer bay had significantly lower carbon content than the macroalgae transplanted in situ (Table 2; $<<0.01$, ANOVA). The \% nitrogen content increased initially for transplants in the inner bay and declined for those in the low-nutrient outer bay, reflecting, in part, the change in tissue nitrate levels (Fig. 2). After Day 4, the nitrogen content declined in macroalgae from both sites (Fig. $3 ; p>0.05$, ANOVAR). At the end of the experiment, the nitrogen content of macroalgae in the outer bay was $57 \%$ lower than that of macroalgae in the high-nutrient inner bay (Fig. 3, Table 2; $\mathrm{p}<0.001$, ANOVA). For macroalgae transplanted to the low-nutrient outer bay, the phosphorus content declined during the first $6 \mathrm{~d}$ then remained constant at about $50 \%$ of the initial level until the end of the experiment, in contrast to inner bay transplants where the phosphorus content increased slightly over the course of the experiment (Fig. 3; $p<0.05$, ANOVAR). By the end of the experiment, the phosphorus content of macroalgae transplanted to the outer bay was $60 \%$ lower than that of macroalgae transplanted in situ (Table $2 ; \mathrm{p}<0.001$. ANOVA).

This marked decline in both the nitrogen and phosphorus contents of macroalgae tranplanted to the low-nutrient outer bay was also evident in the molar

Table 1. Spyridea hypnoides. Tissue composition of pooled samples (mean \pm SE) on Day 14, the final day of the transplant experiment. Macroalgae transplanted to the low-nutrient outer Bailey's Bay were compared with macroalgae transplanted in situ (inner Bailey's Bay) and with unmanipulated controls in the inner (eutrophic) bay

\begin{tabular}{|lcccc|}
\hline Treatment & $\begin{array}{c}\mathrm{NO}_{2}^{-}+\mathrm{NO}_{3}^{-} \\
\left(\mu \mathrm{mol} \mathrm{g}^{-1} \text { wet wt }\right)\end{array}$ & $\begin{array}{c}\text { Protein } \\
\left(\mathrm{mg} \mathrm{g}^{-1} \text { wet wt }\right)\end{array}$ & $\begin{array}{c}\text { Chl } a \\
\left(\mathrm{mg} \mathrm{g}^{-1} \text { wet wt }\right)\end{array}$ & $\begin{array}{c}\text { Starch } \\
(\% \mathrm{dry} \text { wt })\end{array}$ \\
\hline Outer bay transplant & $0.14 \pm 0.02$ & $9.62 \pm 0.36$ & $1.10 \pm 0.07$ & $3.13 \pm 0.02$ \\
Inner bay transplant & $8.00 \pm 0.33$ & $21.21 \pm 1.19$ & $4.32 \pm 0.51$ & $4.85 \pm 0.25$ \\
Unmanipulated control & $7.64 \pm 0.19$ & $22.13 \pm 2.45$ & $4.20 \pm 0.01$ & $2.91 \pm 0.10$ \\
\hline
\end{tabular}



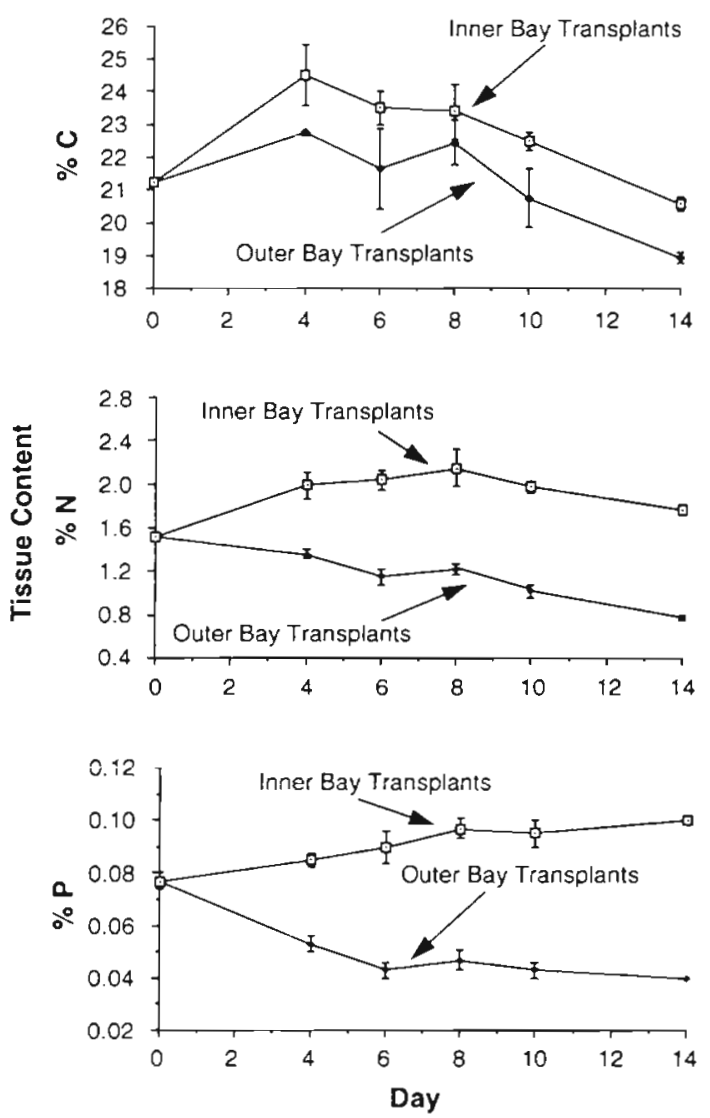

Fig. 3. Spyridea hypnoides. Mean carbon, nitrogen, and phosphorus contents of transplants collected from triplicate cages in the high-nutrient inner bay and in the low-nutrient outer bay over the course of the 2 wk experiment. These values were calculated as the percent of sample dry wt. Error bars represent $\pm 1 \mathrm{SE}$ for 3 samples for each treatment. Samples

from replicate cages were pooled on Days 0 and 14

ratios derived from these weight $\%$ values. At the end of the 2 wk transplant period, both the $\mathrm{C}: \mathrm{N}$ and the $\mathrm{C}: \mathrm{P}$ ratios were $2 \times$ higher for macroalgae from the outer bay than for those remaining in situ (Table 2). The N: $P$ ratios, however, did not change during the experiment nor was there a difference between treatments (Table 2). There was no strong transplant effect on this aspect of the macroalgal physiology; the phosphorus content of transplants in the inner bay and unmanipulated control algae were virtually identical, whereas the carbon and nitrogen contents in the transplants were slightly lower, by 8 and $14 \%$ respectively.

\section{Photosynthesis vs irradiance relationships}

After $2 \mathrm{wk}$, macroalgae exposed to the low-nutrient conditions in the outer bay showed markedly different photosynthetic responses to irradiance levels than macroalgae transplanted in situ in the inner bay (Fig. 4). For macroalgae in the low-nutrient outer bay the metabolic cost of respiration was higher when normalized to chlorophyll content, with mean rates approximately $50 \%$ greater than that for macroalgae remaining in situ (Fig. 4a, Table 3i $\mathrm{p}<0.053$, paired $t$-test). $P_{\max }$ was not different between the transplants in the inner and outer bay (Table $3 ; p>0.05$, paired $t$-test). However, given the significantly reduced chlorophyll content of the macroalgae transplanted to the outer bay, these photosynthetic rates were approximately $75 \%$ lower than those of macroalgae from the high-nutrient inner bay when normalized to biomass (Fig. 4b).

On a chlorophyll basis, the initial slope of the photosynthesis-irradiance curve $(\alpha)$ was significantly higher in the macroalgae transplanted to the outer bay (Table 3; $p<0.05$, paired $t$-test), indicating a greater photosynthetic efficiency at low irradiances. Macroalgae from the low-nutrient outer bay also reached the saturation level of photosynthesis at a lower irradiance (Fig. 4a). The calculated $l_{k}$ for transplants in the outer bay was roughly $50 \%$ of that from macroalgae in the high-nutrient inner bay (Table $3 ; \mathrm{p}<0.05$, paired $t$-test). However, given the higher $\alpha$ for macroalgae from the outer bay, the irradiance level where net photosynthesis equals zero $\left(I_{c}\right)$ was not different between the treatments (Table $3 ; \mathrm{p}>0.05$, paired $t$-test). There were no significant differences in any of the parameters of the P vs I relationship between the macroalgae transplanted in situ and the unmanipulated controls (Table 3; $\mathrm{p}>0.05$, paired $t$-test).

Table 2. Spyridea hypnoides. Total carbon, nitrogen and phosphorus content of transplants as compared to the unmanipulated control macroalgae. Elemental concentrations are given as percent of total dry wt. Molar ratios of the elements were calculated as the average ratios of individual samples. Values represent means $\pm 1 \mathrm{SE}$

\begin{tabular}{|lccccccc}
\hline Treatment & $\% \mathrm{C}$ & $\% \mathrm{~N}$ & $\% \mathrm{P}$ & $\begin{array}{c}\mathrm{C}: \mathrm{N} \\
\text { (molar ratio) }\end{array}$ & $\begin{array}{c}\mathrm{C}: \mathrm{P} \\
\text { (molar ratio) }\end{array}$ & $\begin{array}{c}\mathrm{N}: \mathrm{P} \\
\text { (molar ratio) }\end{array}$ \\
\hline Outer bay transplant & $18.93 \pm 0.19$ & $0.77 \pm 0.02$ & $0.04 \pm 0$ & $28.84 \pm 0.60$ & $1222.35 \pm 12.06$ & $42.44 \pm 1.29$ \\
Inner bay transplant & $20.56 \pm 0.22$ & $1.77 \pm 0.05$ & $0.10 \pm 0$ & $13.59 \pm 0.21$ & $531.22 \pm 5.70$ & $39.12 \pm 1.03$ \\
Unmanipulated control & $22.45 \pm 0.27$ & $2.07 \pm 0.04$ & $0.10 \pm 0$ & $12.68 \pm 0.11$ & $580.05 \pm 6.82$ & $45.76 \pm 0.93$ \\
\hline
\end{tabular}



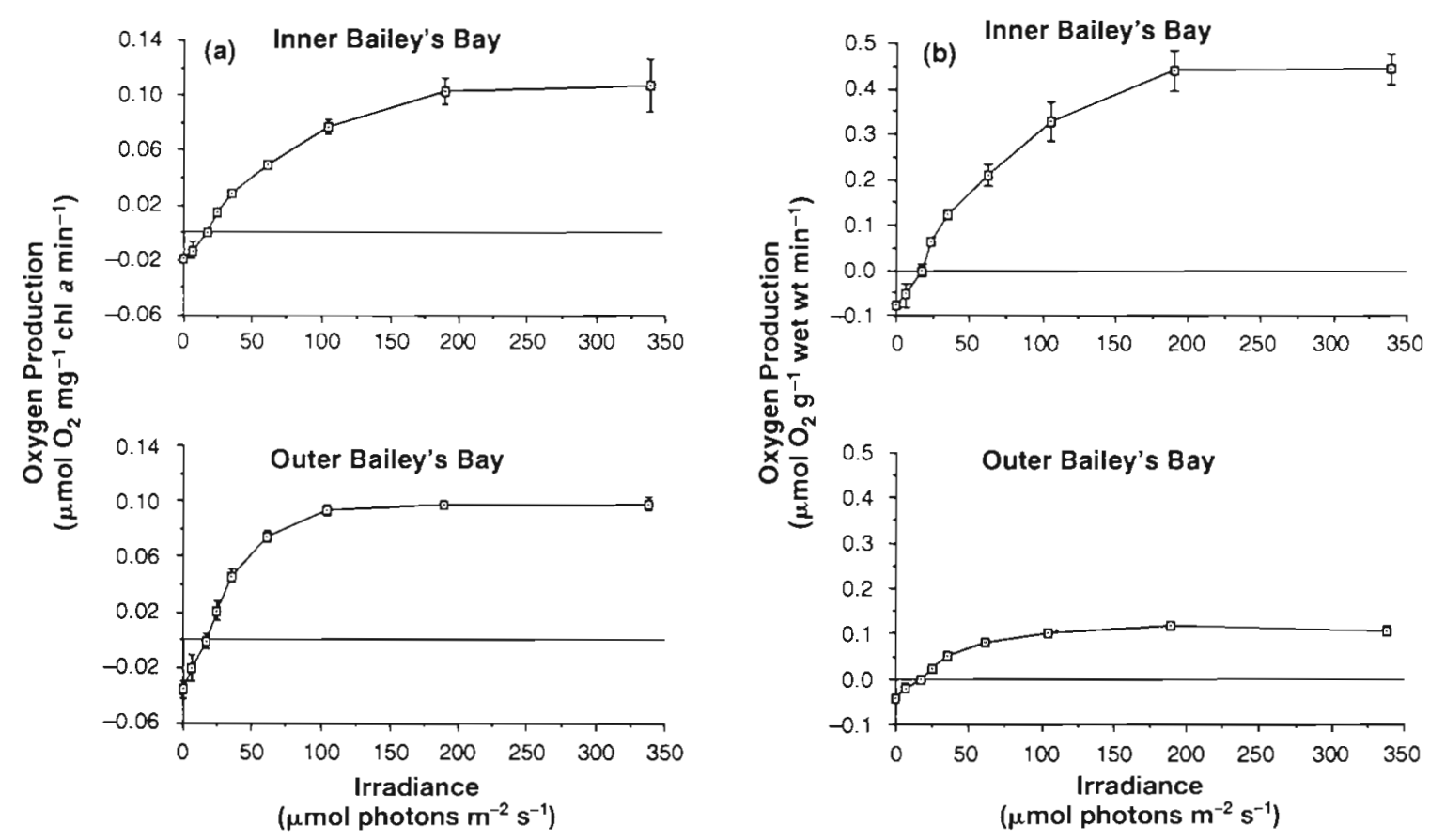

Fig. 4. Spyridea hypnoides. Photosynthesis vs irradiance relationships of samples from the inner and outer bay at the conclusion of the 2 wk transplant experiment. Rates of photosynthesis were measured as oxygen evolution in closed incubation chambers and normalized to (a) chlorophyll content or (b) biomass. Values are means $(n=3) \pm 1 \mathrm{SE}$

\section{DISCUSSION}

The change in tissue nitrate concentration in Spyridea hypnoides in the inner bay over the course of the experiment, which roughly mirrored the ambient nitrite+nitrate levels, indicates that these macroalgae are capable of accumulating dissolved nitrate. These pools may have accumulated either because resource supply exceeded the metabolic demand for growth and maintenance (Chapman \& Craigie 1977, Rosenberg \& Ramus 1982, Asare \& Harlin 1983), or because nitrate reductase activity was the rate-limiting step in nitrogen assimilation (Hwang et al. 1987, Raimbault \& Mingazzini 1987, Martinez 1991). Where membrane transport exceeds the nitrate reductase activity, nitrate pools may accumulate from the uncoupling of uptake and reduction (Raimbault \& Mingazzini 1987). Although many macroalgal species are known to accumulate nitrate, most studies have considered the seasonal fluctuations of tissue nitrate in response to ambient nutrient concentrations and metabolic demands (Chapman \& Craigie 1977, Rosenberg \& Ramus 1982, Asare $\&$ Harlin 1983). This study shows that the accumulation and depletion of nitrate pools in S. hypnoides can occur on a much shorter time scale with marked changes in tissue nitrate pools closely following the daily variations in ambient nutrient levels.

The accumulated nitrate pools in Spyridea hypnoides from the high-nutrient inner bay, however, provided little buffering against reductions in external nutrient levels, and were exhausted when nitrate resupply from the external environment was chronically low. Macroalgae transplanted to the low-nutrient outer bay, where ambient nitrate concentrations were 2 to $10 \times$ below that

Table 3. Spyridea hypnoides. Parameters of the photosynthesis vs irradiance (P vs I) relationship of transplants and unmanipulated control macroalgae. $P_{\max }$ : asymptotic level of photosynthesis; $\alpha$ slope of the P vs I curve; $I_{\mathrm{k}}$ : saturating irradiance; $I_{c}$ : irradiance where net $P_{\max }=0$. Values represent means $(\mathrm{n}=3) \pm 1 \mathrm{SE}$

\begin{tabular}{|c|c|c|c|c|c|}
\hline Treatment & $\begin{array}{c}P_{\max } \\
\left(\mu \mathrm{mol} \mathrm{O} \mathrm{O}_{2} \mathrm{~m}\right.\end{array}$ & $\begin{array}{l}\text { Respiration } \\
\left.-1 \mathrm{chl} a \min ^{-1}\right)\end{array}$ & 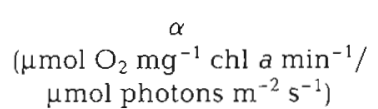 & \multicolumn{2}{|c|}{$\begin{array}{c}I_{\mathrm{k}} \\
\left(\mu \mathrm{mol} \text { photons } \mathrm{m}^{-2} \mathrm{~s}^{-1}\right)\end{array}$} \\
\hline Outer bay transplant & $0.101 \pm 0.001$ & $-0.036 \pm 0.006$ & $0.0032 \pm 0.0003$ & $43.39 \pm 3.20$ & $15.70 \pm 2.58$ \\
\hline Inner bay transplant. & $0.114 \pm 0.018$ & $-0.019 \pm 0.003$ & $0.0016 \pm 0$ & $80.79+10.49$ & $14.34 \pm 1.61$ \\
\hline Unmanipulated control & $0.125 \pm 0.007$ & $-0.024 \pm 0.004$ & $0.0018 \pm 0.0002$ & $82.53 \pm 7.29$ & $15.60 \pm 0.92$ \\
\hline
\end{tabular}


of the inner bay, experienced a rapid reduction of internal nitrate pools, losing $93 \%$ of the initial soluble tissue nitrate after 4 d (Fig. 2). Thomas \& Harrison (1985) showed a similar decline in tissue nitrate pools in the temperate rhodophyte Porphyra perforata, after $3 \mathrm{~d}$ of nitrate deprivation and attributed this partly to an increase in reductase activity in order to utilize internal nitrate pools. For $S$. hypnoides, the depleted nitrate pools were not replenished at low ambient nutrient concentrations and the tissue nitrate levels of the outerbay transplants remained at near undetectable levels for the duration of the 2 wk study.

A significant portion of tissue nitrogen is associated with the light harvesting apparatus and several studies have shown that amino acids and proteins are major nitrogen storage reserves in macroalgae (Lapointe 1981, Bird et al. 1982, Rosenberg \& Ramus 1982, Hwang et al. 1987). The severe bleaching of Spyridea hypnoides transplants after $4 \mathrm{~d}$ in the outer bay indicates that there was a reduction in pigments (e.g. chlorophyll and phycoerytherin) and is consistent with other work showing the rapid utilization of proteinaceous pigments with nitrogen deficiency (Ryther et al. 1981, Bird et al. 1982, Lapointe \& Duke 1984, Ben-Amotz 1987). At the end of the 2 wk transplant experiment, both chlorophyll and protein pools in macroalgae in the outer bay were lower than those of macroalgae from the high-nutrient inner bay by 75 and $55 \%$ respectively (Table 1 ). This was probably due to either insufficient nitrogen to support protein synthesis (Bird et al. 1982) or to the degradation of proteins as storage compounds (Cooke et al, 1979, Lapointe \& Duke 1984). The marked decline in protein content in the outer bay transplants also may have been partly due to a reduction in photosynthetic enzymes associated with the lower tissue nitrogen content (Kuppers \& Weidner 1980).

In nutrient-deficient Spyridea hypnoides, both nitrogen and phosphorus contents decreased simultaneously such that the $N$ :P ratios remained essentially unchanged during the experiment. Bjornsater \& Wheeler (1990) found a comparable decline in the phosphate content of Enteromorpha intestinalis and Ulva fenestrata when these macroalgae were nitrogen limited. Phosphate pools in macroalgae are primarily polyphosphates and these stores can be depleted by enzymatic hydrolysis (Lin 1977) at times of nutrient stress. This balance between nitrogen and phosphorus under nitrogen stress is consistent with other studies on nitrogen-limited macroalgae (Gordon et al. 1981, Bjornsater \& Wheeler 1990) and may indicate a coupling of nitrogen and phosphorus metabolism. The relative decline in total carbon concentration, however, was small compared to that of both the nitrogen and phosphorus contents, as illustrated by the elevated
$\mathrm{C}: \mathrm{N}$ and $\mathrm{C}: \mathrm{P}$ ratios in the macroalgae transplanted to the outer bay (Table 2). An increase in the $C: N$ ratio of nitrogen-deficient macroalgae is common (Bird et al. 1982, Lapointe \& Duke 1984, Laws \& Caperon 1986), and often represents an accumulation of reserve carbohydrates in excess of growth requirements when nitrogen availability is low (Bird et al. 1982, Rosenberg \& Ramus 1982). Under conditions of nutrient stress, macroalgae can use either reserve carbohydrates or recently fixed transient sugars to meet the metabolic requirements for nutrient assimilation and growth (Ryther et al. 1981, Bird et al. 1982, Rosenberg \& Ramus 1982). Given the low starch content of outer bay transplants relative to those in the inner bay, it is tempting to suggest that the macroalgae were using membrane-bound reserve carbohydrates to meet metabolic demands. These results, however, are equivocal, as there were no differences between outer bay transplants and unmanipulated control algae. The lack of a strong relationship between starch content and tissue nitrogen levels in $S$. hypnoides and the marked decline in photosynthetic rates of outer bay transplants suggest. that it was primarily the recent products of photosynthesis that were being used to meet metabolic requirements.

The nitrogen budget of macroalgae is strongly linked to photosynthetic performance, in terms of both the efficiency of light harvesting and electron transport and the capacity for carbon fixation. For Spyridea hypnoides transplanted to the low-nutrient outer bay, the absolute amounts of both chlorophyll and protein declined, but the photosynthetic efficiency per unit chlorophyll $\left(\alpha_{c h l}\right)$ increased. These macroalgae were more efficient at low irradiances, as indicated by the steeper slope $(\alpha)$ of the light-limited portion of the P vs I curve (Fig. 4a, Table 3). An increase in the $\alpha_{\text {chl }}$ has also been shown for nitrogen-limited phytoplankton and has been associated with a reduction in thylakoid stacking and absorptivity (Turpin 1991 and references therein). The costs of nutrient deprivation, however, were manifested in the 2-fold higher respiration rate (chlorophyll basis) of the outer bay transplants (Fig. $4 \mathrm{a}$ ). This suggests that carbon fixation for these macroalgae was not limited by the light capturing and electron transport system, but rather by the need to acquire sufficient nitrogen to support protein synthesis necessary for the carboxylation of $\mathrm{CO}_{2}$.

Despite the increased photosynthetic efficiency of Spyridea hypnoides in the low-nutrient outer bay, the decreased carbon gain of these macroalgae will ultimately lead to a decline in overall growth rates. Biomass-specific $P_{\max }$ declined dramatically for macroalgae in the outer bay after $2 \mathrm{wk}$, where rates were one-quarter that of inner bay transplants (Fig. 4 b). This result contrasts that of a similar transplant study of the 
giant kelp Macrocystis pyrifera, where Gerard (1982) showed that internal nitrogen reserves were capable of sustaining high growth rates for $2 \mathrm{wk}$ in a low nutrient environment. For $S$. hypnoides, however, nitrogen stores were insufficient to meet the metabolic needs for growth and maintenance when ambient nitrate concentrations were chronically low. The reduced carbon fixation in nitrogen-deficient macroalgae may be due to the lower activity of proteinaceous photosynthetic enzymes when nitrogen is limiting (Kuppers \& Weidner 1980, Lapointe \& Duke 1984) or to the diversion of photosynthetic intermediates to support transient nitrogen assimilation (Williams \& Herbert 1989).

Macroalgae with rapid nutrient uptake and growth potentials typically are dominant in eutrophic environments with a high nutrient supply (Fujita 1985, Valiela et al. 1990). These same species appear to be absent from low-nutrient habitats because they lack the ability to acquire sufficient resources to meet the metabolic needs of maintenance and growth. Given the consistently high nutrient levels typical of the environments in which these macroalgae dominate, there is little adaptive advantage to developing nutrient storage abilities. For these species, most acquired nutrients appear to be allocated to growth rather than to storage reserves, suggesting that a physiological cost of rapid growth is a decreased capacity for reserve storage to act as a buffer against the asynchrony of supply and demand. Without a well-developed storage capacity, Spyridea hypnoides experiences a variable nitrogen supply and it would be expected that the tissue nitrogen content would fluctuate with ambient nitrogen levels, as this species must depend on rapid nutrient uptake to meet metabolic demands. By virtue of its high surface area-to-volume ratio, $S$. hypnoides, like other filamentous, mat-forming macroalgae, may be able to exploit patchy nutrient resources efficiently (Rosenberg \& Ramus 1984, Carpenter 1990). This will be advantageous when nutrient pulses are frequent or when ambient levels are consistently high in eutrophic environments, but without the capacity to build significant storage reserves, $S$. hypnoides is vulnerable to nutrient stress in environments where the nutrient supply is chronically low. For $S$. hypnoides, the stress imposed by low nitrogen availability was manifested in a reduction of photosynthetic capacity, illustrating the strong coupling bewteen nitrogen and carbon metabolism. These physiological characteristics are important in setting potential limits on macroalgal distributions, within which it is possible to evaluate the relative effects of both physical (e.g. disturbance) and biological (e.g. competition, grazing) factors in determining community structure.
Acknowledgements. I thank R. Howarth, W. Dennison, T. Dawson, N. Hairston, Jr, S. Levin, and 2 anonymous reviewers for valuable comments on an earlier version of this manuscript. Discussions with $W$. Dennison and $T$ Dawson were especially helpful throughout the project. I also thank D. Westphalen and R. Marino for their assistance in the field and laboratory work. B. Lewis was generous in offering her laboratory facilities for the starch analysis, and $T$ Dawson, A. Michaels, and C. Cook provided essential laboratory equipment. Partial funding for this project was provided by the Samuel Riker and Roger Stone Fellowships from the Bermuda Biological Station for Research to K. McGlathery and NSF grant BSR-8905364 to R. Howarth. This is Contribution \#1323 from the Bermuda Biological Station for Research.

\section{LITERATURE CITED}

Aman, P., Hesselman, K. (1984). Analysis of starch and other main constituents of cereal grains. Swed. J. agric. Res. 14: $135-139$

Asare, S. O., Harlin, M. M. (1983). Seasonal fluctuations in tissue nitrogen for five species of perrenial macroalgae in Rhode Island Sound. J. Phycol. 19: 254-257

Batey, I. L. (1982). Starch analysis using thermostable $\alpha$ amylases. Starch 34: 125-128

Ben-Amotz, A. (1987). Effect of irradiance and nutrient deficiency on the chemical composition of Dunaliella bardawil Ben-Amotz and Avron (Volvocales, Chlorophyta). Plant Physiol. 131: 467-478

Bird, K. T., Habig, C., DeBusk, T (1982). Nitrogen allocation and storage patterns in Gracilaria tikvahiae (Rhodophyta). J. Phycol. 18: 344-348

Bjornsater, B. R., Wheeler, A. (1990). Effect of nitrogen and phosphorus supply on growth and tissue composition of Ulva fenestrata and Enteromorpha intestinalis (Ulvales, Chlorophyta). J. Phycol. 26: 603-611

Carpenter, R. C. (1990). Competition among marine macroalgae: a physiological perspective. J. Phycol. 26: 6-12

Chapman, A. R. O., Craigie, J. S. (1977). Seasonal growth in Laminaria longicruris: relations with dissolved inorganic nutrients and internal reserves of nitrogen. Mar. Biol. 40 . $197-205$

Cooke, R. J., Oliver, J., Davies, D. D. (1979). Stress and protein turnover in Lemna minor. Plant Physiol. 64: 1109-1113

Duke, C. S., Litaker, W., Ramus, J. (1989). Effects of temperature, nitrogen supply, and tissue nitrogen on ammonium uptake of the chlorophyte seaweeds UIva curvata and Codium decorticatum. J. Phycol. 25: 113-120

Fujita, R. M. (1985). The role of nitrogen status in regulating transient ammonium uptake and nitrogen storage by macroalgae. J. exp. mar. Biol. Ecol. 92: 283-301

Gerard, V. A. (1982). Growth and utilization of internal nitrogen reserves by the giant kelp Macrocystis pyrifera in a low-nitrogen environment. Mar. Biol. 66: 27-35

Gordon, D. M., Birch, P. B., McComb, A. J. (1981). Effects of inorganic phosphorus and nitrogen on the growth of an estuarine Cladophora in culture. Bot. Mar. 24: 93-106

Grasshoff, K., Erhardt, M., Kremling, K. (1983). Methods of seawater analysis. Verlag Chemie, Weinheim

Hwang, S.-P. L., Williams, S. L., Brinkhuis, B. H. (1987). (hanges in internal dissolved nitrogen pools as related to nitrogen uptake and assimilation in Gracilaria tikvahiae McLachlan (Rhodophyta). Bot. Mar. 30: 11-19

Kuppers, U., Weidner, M. (1980). Seasonal variations of enzyme activity in Laminaria hyperborea. Planta 148:222-230 
Kursar, T. A., Alberte, R. S. (1983). Photosynthetic unit organization in a red alga: relationships between lightharvesting pigments and reaction centers. Plant Physiol. 72: $409-414$

Lapointe, B. E. (1981). The effects of light and nitrogen on growth, pigment content, and biochemical composition of Gracilaria foliifera v. angustissima (Gigartinales, Rhodophyta). J. Phycol. 17: 90-95

Lapointe, B. E., Duke, C. S. (1984). Biochemical strategies for growth of Gracilaria tikvahiae (Rhodophyta) in relation to light intensity and nitrogen availability. J. Phycol. 20: 488-495

Laws, E. A., Caperon, J. (1986). Carbon and nitrogen metabolism by Monochrysis lutheri: measurement of growth rate-dependent respiration rates. Mar. Biol. 36: 85-97

Lin, C. K. (1977). Accumulation of water soluble phosphorus and hydrolysis of polyphosphates by Cladophora glomerata (Chlorophyta). J. Phycol. 13: 46-51

Littler, M. M., Littler, D. S. (1980). The evolution of thallus form and survival strategies in benthic marine macroalgae: field and laboratory tests of a functional form model. Am. Nat. 116: 25-44

Martinez, R. (1991). Transient nitrate uptake and assimilation in Skeletonema costatum cultures subject to nitrate starvation under low irradiance. J. Plankton Res. 13: 499-512

McGlathery, K. J. (1992). Nutrient and herbivore influences on seagrass community dynamics. Ph.D. thesis, Section of Ecology and Systematics, Cornell Univ.

Potvin, C., Lechowicz, M. J., Tardif, S. (1990). The statistical analysis of ecophysiological response curves obtained from experiments involving repeated measures. Ecology 71: $1389-1400$

Raimbault, P., Mingazzini, M. (1987). Diurnal variations of intracellular nitrate storage by marine diatoms: effects of nutritional state. J. exp. mar. Biol. Ecol. 112: 217-232

This article was submitted to the editor
Ramus, J., Venable, M. (1987). Temporal ammonium patchiness and growth rate in Codium and Ulva (Ulvophyceae). J. Phycol. 32: 518-523

Rosenberg, G.. Ramus, J. (1982). Ecological growth strategies in the seaweeds Gracilaria folifera (Rhodophyceae) and Ulva sp. (Chlorophyceae): soluble nitrogen and reserve carbohydrates. Mar. Biol. 66: 251-259

Rosenberg, G., Ramus, J. (1984). Uptake of inorganic nitrogen and seaweed surface:volume ratio. Aquat. Bot. 19: 65-72

Ryther, J. H., Corwin, N., DeBusk, T. A., Williams, L. D. (1981). Nitrogen uptake and storage by the red alga Gracilaria tikvahiae (McLachlan, 1979). Aquaculture 26: $107-115$

Smith, P. K., Krohn, R. I., Hermanson, G. T., Mallia, A. K., Gartner, F. H., Provenzano, M. D., Fujimoto, E. K., Goeke, N. M., Olsen, B. J., Klenk, D. C. (1985). Measurement of protein using bicichoninic acid. Anal. Biochem. 150: $76-85$

Stainton, M. P., Capel, M. J, Armstrong, F. A. (1974). The chemical analysis of freshwater. Miscellaneous Special Publication 25, Dept of the Environment, Freshwater Institute, Research Development Directorate, Winnipeg

Thomas, T. E., Harrison, P. J. (1985). Effect of nitrogen supply on nitrogen uptake, accumulation and assimilation in Porphyra perforata (Rhodophyta). Mar. Biol. 85: 269-278

Turpin, D. H. (1991). Effects of inorganic $N$ availability on algal photosynthesis and carbon metabolism. J. Phycol. 27: $14-20$

Valiela, I., Costa, J., Foreman, K, Teal, J. M., Howes, B., Aubrey, B. (1990). Transport of groundwater-borne nutrients from watersheds and their effects on coastal waters. Biogeochem. 10: 177-197

Williams, S. L., Herbert, S. K. (1989). Transient photosynthetic responses of nitrogen-deprived Petalonia fascia and Laminaria saccharina (Phaeophyta) to ammonium resupply. J. Phycol. 25: 515-522

Manuscript first received: January 20, 1992

Revised version accepted: July 31, 1992 